\title{
THE HEDGEHOG'S DILEMMA IN ORGANIZATIONS: THE PROS AND CONS OF WORKPLACE FRIENDSHIP
}

Can BíÇER ${ }^{1}$

Citation/( $)$ : Biçer, C. (2020). The Hedgehog's dilemma in organizations: The pros and cons of workplace friendship. Hitit University Journal of Social Sciences Institute, 13(1), 201-217. doi: 10.17218.hititsosbil.741565

Abstract: There are numerous studies about the benefits of workplace friendship in organizations. Therefore, it may be assumed that well-established friendships in organizations promote effective information sharing, communication skills, increase teamwork and workplace morale among employees at work. Additionally, workplace friendships have positive effects for the organizations such as lower turnover rates, employee burnout and lower levels of intention to leave. On the other hand, just like experiencing the hedgehog's dilemma, higher levels of workplace friendship or intimacy among group of individuals in organizations may lead to negative consequences such as the supervisor/subordinate friendship may raise the anger or feelings of unfair treatment by other individuals or may lead to untrue performance assessments. Besides, workplace friendships may cause failures to report misfits and counterproductive work behaviors accurately in the organizations. So, workflow might deteriorate and it may lead to conflicts in teamwork in organizations. In sum, in this conceptual paper, workplace friendship will be focused on and the advantages and the disadvantages of it will be outlined. Then, in the conclusion section, the recommendations will be made about how to reduce the negative effects of workplace friendships in organizations.

Keywords: The Hedgehog's Dilemma, Friendship, Workplace Friendship

\section{Örgütlerde Kirpi İkilemi: İşyeri Arkadaşlıklarının Olumlu ve Olumsuz Yönleri}

Atıf/C: Biçer, C. (2020). Örgütlerde kirpi ikilemi: İşyeri arkadaşl1klarının olumlu ve olumsuz yönleri, Hitit Üniversitesi Sosyal Bilimler Enstitüsü Dergisi, 13(1), 201-217. doi: 10.17218.hititsosbil.741565

Özet: Örgütlerdeki işyeri arkadaşlıklarının faydalarıyla ilgili çok fazla çalışma bulunmaktadır. Bu yüzden, işyerinde iyi temeller üzerine kurulmuş olan işyeri arkadaşlıklarının etkin bilgi paylaşımını ve iletişim becerilerinin desteklediğini, ekip çalışmasını ve çalışanların moralini artırdığı düşünülebilir. Buna ek olarak, işyeri arkadaşlıklarının düşük iş gücü devir oranları, daha düşük seviyelerde çalışan tükenmişliği ve işten ayrılma niyeti gibi olumlu örgütsel etkilere sahiptir. Öte yandan, tıpkı kirpi ikilemindeki gibi yüksek düzeylerdeki arkadaşlıklar ve grup içi yakınlıklar, örgütlerde olumsuz sonuçlara neden olabilir ve ast/üst düzeyindeki arkadaşlıklar diğer bireylerin öfke duymalarına veya adil olmayan muameleye tabi tutulduklarını ve gerçeği yansıtmayan performans değerlemelerinin olduğunu düşünmelerine yol açabilir. Bununla birlikte işyeri arkadaşlıkları örgütlerde ters giden bir şeylerin ve amaca yönelik olmayan çalışma davranışlarını düzgün bir şekilde bildirilmesinde zafiyete neden olabilir. Bu nedenle, iş akışı bozulabilir ve örgütlerdeki takım çalışmalarında çatışmalara neden olabilir. Özetle bu çalışmada işyeri arkadaşları ele alınacak ve olumlu ve olumsuz yönleri irdelenecektir. Daha sonra, sonuç bölümünde, örgütlerde işyeri arkadaşlıklarının olumsuz yönlerinin azaltılmasına yönelik önerilerde bulunulacaktır.

Anahtar Kelimeler: Kirpi İkilemi, Arkadaşlık, İşyeri Arkadaşlığ

Makale Geliş Tarihi: 22.05.2020 Makale Kabul Tarihi: 29.6.2020

${ }^{1}$ Dr. Öğr. Üyesi, Karabük Üniversitesi, Safranbolu Meslek Yüksekokulu, Seyahat-Turizm ve Eğlence Hizmetleri Bölümü, canbicer@karabuk.edu.tr, http://orcid.org/0000-0001-7270-7417 


\section{Can BİÇER}

\section{INTRODUCTION}

As most of the people see their coworkers or managers more than any of the family member, it's so real that people at work become friends or more than friends while they are performing their duties because there will be lots of reasons that workplace friendship or even romance tend to bloom at workplace. Employees who realize that they have a lot in common with other coworkers begin to spend much time from doing their jobs together to going out for lunch or doing social activities off the work. Besides, when two or more people can find common ground at workplaces, then they work on projects efficiently and discuss about them easily, offer sincere advice or help, they face the same stressors and they look forward to the same weekend or holidays for having good time. In growing body of literature, it has been maintained that friendships have positive effects on working environment. For example, Bartels et al. (2019) stated that satisfaction with colleagues and friendships at workplace can deeply affect an employee's job and life satisfaction as well. In addition, Colbert et al. (2016) argued in their study that work relationships may be a "source of enrichment, vitality, and learning that help individuals, groups, and organizations grow, thrive, and flourish, and workplace friendships enable more than task assistance, career advancement, and emotional support in organizations. Furthermore, as Li and Hung (2009) mentioned in their study, individuals are often prone to classify themselves and others into various social categories within the concept of social-identity theory and the two main social relationships in the workplace are the leader-member relationships and coworker relationships in organizations. In addition, it has been emphasized that the interpersonal relationships between leaders, subordinates, and coworkers forms an interconnected social system that functions at workplaces. However, it has also been outlined that the leader-member relationship is determinant of a worker's social-exchange relationship with his or her manager/supervisor, and it is most usually stated by leader-member exchange (LMX) quality since LMX is commonly based on the notion that that leaders develop different types of exchange relationships with their followers and higher quality leader-member relationships are defined by high levels of mutual trust, intimacy, caring, respect, loyalty and socio-emotional benefits which are the basic elements of workplace friendships and for the friendship partners at workplaces.

Friendships at workplaces are mostly viewed seen as being beneficial but friendships may also generate complexities and tensions for those inside and outside the circle in the organizations. Hence, workplace friendships might create tension or stress when it is time to decide about promotions, sharing the resources especially when they are scarce or group decision-making situations when raising hard questions about the organizational goals among groups of friends. Moreover, workplace friendships may jeopardize the working environment due to too much chatting or too much socializing among friends may hamper productivity and confidential, personal or professional information might be revealed to inappropriate people which then it may lead to unprofessional environment at workplace. For example, Khaleel et al. (2016) highlighted in their study that workplace friendship usually ends up with sexual harassment, romantic relationship that lead to loss of productivity, conflict of interest, and office romance and office gossips in the organizations. To sum up, Sias et al. (1998) maintained that whether it can be regarded as good or bad, workplace friendships are the important fact of the organizing process. Hence, in this conceptual study, within the scope of the "Hedgehog's Dilemma" which is a metaphor about the challenges of workplace friendship", describing the situation in which the hedgehogs want to share the heat during cold weather by coming closer to each other but since they have got sharp spines on their backs, they will hurt each other if they get too close. Just like in this dilemma, when friends come too closer each other, they might both harm themselves and others, if not, they might be negatively affected by the external, namely psychological or other 
reasons, for example being lonely and isolated in the organization. In short, the closer friends become, the more deeply they may hurt each other and cause friction at work. Finally, friendship is a unique and undeniable dimension of the workplaces and it's often regarded as workplaces are the main crucible for making friends. Since workplace friendship is the indispensable part of the organizations, the key problem of this study is to define the well-balanced workplace friendship in organizations in order to benefit the positive outcomes of the friendships and prevent from the disadvantages of friendships and their negative outcomes because when friendships deteriorate, it can lead to huge hidden costs for the organization such as decreasing organization's productivity, destructing workflow, unity and coherence in the organization, hampering the communication among individuals and may wipe out the organization's reputation in the end. So, in this study workplace friendships will be outlined through literatüre overview and the pros and cons of the workplace friendships will be enlightened for both the employees and organizations and in conclusion section, the recommendations will be made for reaching the optimum level for well-balanced workplace friendships in organizations.

\section{WORKPLACE FRIENDSHIPS}

As humans are highly social beings, they like to be surrounded by friends and tend to share their personal views and experiences with others. We the people have the tendency to associate, interact, and bond with others who have the same characteristics and backgrounds. Friendship refers to a wide range of interpersonal relations that are started, developed and may be quit voluntarily. Friendship is a form of intimacy that seems to be very important in modern urbanizing, mobile, and interconnected world (Bunnel, 2017, pp. 1-2). Chung et al. (2017) stated in their study that friendship principally depends on the positive experiences of interacting and working with others and friendship only exists when the relationship comprises of all three components such as liking behaviors, shared experiences, and reciprocity. In addition to this, Mao and Hsieh (2017) argued that friendship is a fundamental feature of human nature and the development of friendships at work is prevalent. Besides, they maintained that friendship leads employees to expect more mutual acceptance, however it also causes conflict or critical evaluation because work roles might create competing interests among them. Berman et al. (2002) maintained that workplaces are sites where individuals can meet each other easily including from coworkers to supervisors or managers because workplaces usually have features that facilitate friendship making among employees. To sum up, as Sharma (2016) indicated that organizations consist of groups of individuals working together on certain organizational goals, it's obvious that workplace friendships naturally develop among employees through mutual relations and expectations, common beliefs and ideas and cooperation to complete work and to achieve corporate goals. Moreover, workplace friendship matters because according to Lin and Lu (2013) employees spend much of their time with coworkers and supervisors and there's no way out for the employees at work but to develop interpersonal relationships and friendships in organizations since we the people are social beings. Besides, they also mentioned that employees are well aware of the benefits of friendships at work such as sharing information effectively and helping each other for their tasks for example working with a friend in an organization, partners of friendships will enjoy their task rather than working with a person who they don't know well or a complete stranger. Additionally, when employees have higher levels of friendships at work, they tend to feel like they're working just like with their family members and they hardly ever think of leaving their organization and it means less turnover rates for the organization. What's more, Lee and Ok (2011) argued that workplace friendship noteworthy for the employees at work because they get better help, assistance, guidance, advice, feedback, recommendations, or information from 


\section{Can BİÇER}

workplace friends on a variety of work-related matters such as completing their jobs, performing tasks, and handling issues with coworkers, subordinates, supervisors, and/or clients and these reflect positively on their task performance and reduce absenteeism.

Workplace friendships are so common in organizations (Tasselli \& Kilduff, 2018, p.803) and they are the nonexclusive workplace relationships often depend on the same interests, shared values, trust, mutual commitment and reciprocal liking between friends at workplaces (Berman et al. 2002, p.2018; Gordon and Hartman, 2009, p. 116). Sias (2005) emphasized that workplace relationships play a vital role in decision-making, influence-sharing, and instrumental and emotional support systems. So it can be inferred that workplace friendships are the most common and one of the strongest relationships in organizations and function as a facilitator in positive organizational outcomes. Moreover, Mao et al. (2012) stated that work relationships often depend on work roles and they are compulsory and are regulated in workflow but friendships develops through voluntary interactions and have a personal focus in organizations. Gordon and Hartman (2009) pointed out that friendships between coworkers can also develop as a result of out-of-work activities, common sense of humor, mutual trust and working on projects together. Hence, Figure 1 ((Berman et al. 2002, pp.217-218; Sias, 2005, p.376; Bader et al, 2013, pp. 94-95; Mao et al. 2012,p.248) shows the significant features of workplace friendships:

Figure 1. The Significant Features of Workplace Friendships
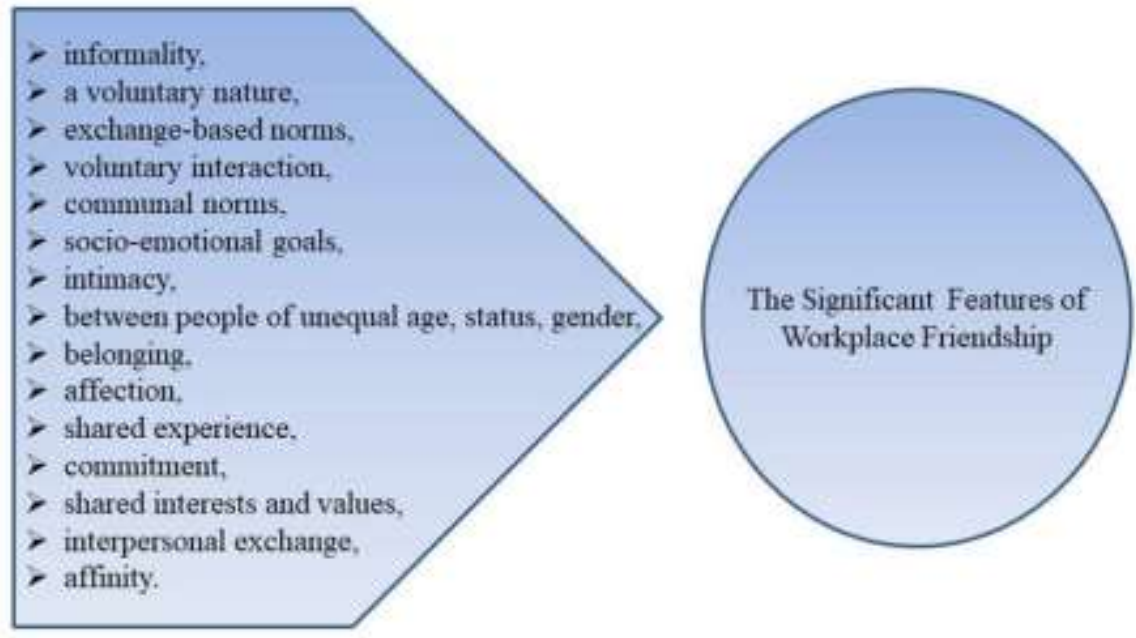

In conclusion, as Morrison and Nolan (2007) highlighted that having friends is almost universally viewed as a favorable thing and friendships within the organizations are not only likely, but practically inevitable, workplace friendships will certainly emerge but since individuals often expect their friends to display special treatment and favoritism, unfair treatments and counterproductive behaviors might appear among group of friends and then, they may lead to discomfort for employees and inefficiency in the organization. Therefore, it's obvious that workplace friendships must be focused on both advantages and disadvantages of workplace friendships for the individuals and organizations.

\section{THE PROS AND CONS Of WORKPLACE FRIENDSHIP}

Workplace friendships can be regarded as a must when thinking that majority of the people who have jobs work at least 40 hours a week with their coworkers and individuals usually have a tendency to associate, interact, and bond with others who have similar characteristics depending on affinity-based similarities and performance at workplaces. As Methot et al. (2017) argued that with the 60-hr workweek viewed typical for most jobs, relationships among coworkers are a vital 
part of a workplace's social environment and workplace friendships often flourish between supervisors and subordinates, leaders and followers, peer coworkers, and employees and external stakeholders through interactions and emotions. Moreover, Riordan and Griffeth (1995) stated that workplace friendship networks emerge in the formal organization and they are part of the employees' everyday association with the formal organization and frequent, dense interaction through close proximity between employees lead to friendship or at least to the opportunity for friendship formations but it has been underlined that the friendship formations and networks that appear within organizations as relevant and powerful interactions that may either jeopardize or facilitate organizational effectiveness. Therefore, it can be claimed that workplace friendships can have a significant effect on both individuals' career and organizational outcomes. In sum, as Berman et al. (2002) underlined, workplace friendship is an essential topic for the organizational structure as many potential benefits may be derived from workplace friendships, for example benefits of workplace friendship refer to formal and informal, vertical and horizontal interactions with open styles of communication and fluid task structures for reaching organizational goals and accomplishments on the whole. So to speak, it has been argued in their study that workplace friendships increase support and resources that assist employees to get their jobs done well and through workplace friendship, employees gain support from others, managers can find allies, instill loyalty and stand up for individuals who support them in the organization.

\subsection{The Pros of Workplace Friendship}

To begin with, as for the advantage of workplace friendship, employees who mention having friends at work have higher levels of productivity, retention, and job satisfaction, and are seven times more likely to be engaged in their work than their "friendless" counterparts at workplaces (Methot et al. 2015, p.2) For example, job embeddedness is one of the positive elements for reaching organizational goals and workplace friendship creates and promotes social links and interaction among employees and eventually, it certainly enhances the job embeddedness and satisfaction (Asgharian et al., 2013, p.17). From the Leader-Member Exchange (LMX) theory which is about the exchange relationship between a leader and an employee has a positive influence on goal commitment, organizational productivity and performance, Song (2009) maintained that workplace friendship creates a more supportive and innovative climate within the organization that results in increased productivity and goal achievement high levels of social exchange between superior and subordinate, by using of motivating language by the superior, have a positive effect on employee performance plus employee productivity and job satisfaction support. In addition, findings in the study support the LMX theory within the concept of emphasizing the importance of workplace friendship to increase the positive work attitudes and performance of employees. In addition, Sias (2005) stated that the most widely-accepted theory regarding supervisorsubordinate relationship quality is the Leader-Member Exchange (LMX) and it has been argued in the study that the leader-member relationship quality is related to a variety of important individual and organizational outcomes. Some other findings have been revealed as follows:

- employees in higher quality relationships report higher levels of job satisfaction and commitment to the organization,

- leader-member relationship quality is negatively related to employee turnover,

- high quality LMX relationships tend to be characterized by high levels of trust and selfdisclosure,

- supervisors and subordinates may communicate more openly more frequently and about more in high quality relationships than in low quality relationships, 


\section{Can BİÇER}

- employees in high quality relationships likely receive more information from their supervisors, than those in low quality relationships.

However, being friends with a manager or boss may cause boundaries being blurred which can make it more difficult to receive the necessary feedback and there is a risk that the other individuals in the organization view a boss as playing favorites at work if there is an obvious special closeness shared with one of the employees as a friend. Just like the hedgehogs, so to speak, keeping the distance eminently, always keeping things professional would be more secure for the partners. For example, it might be so hard for the boss when it comes to make necessary cuts in hours or payroll, even when layoffs or pay cuts are necessary for the survival of the organization.

Furthermore, workplace friendships can really help confidence flourish among employees and work better as a team. According to Greco et al. (2015):

- when employees are too stressful, it's clear that workplace friendships support solidarity and collaboration, and helps them to perform their tasks and duties efficiently by alleviating the stress and unhappy moments and sufferings,

- workplace friendships have a mediating role when any of the employees suffer from the loss of their loved ones, for example, the loss of one of the family members or relatives, by sharing their emotions of suffering and sadness and by showing empathy toward their sorrow to promote their emotional stability and to help in reconstructing the self,

- workplace friendships play a vital role in maintaining or restoring happiness when one of the friends loses his/her job because of any reasons such as economic recession, the end of an employment contract or organizational restructuring. And, friends can also help each other to find a new job by using their own personal contacts.

Additionally, Lee and Ok (2011) maintained that workplace friendship affects work-related attitudes and behaviors of the employees positively and so the organizational outcomes. That is to say, employees can gain advantages such as help, assistance, guidance, advice, feedback, recommendations, or information from their workplace friends on a variety of work-related matters such as completing jobs, undertaking and performing tasks, and dealing with issues with co-workers, subordinates, supervisors, and/or clients at workplace. After all, as itemized information below (Chen et al., 2012, p.719; Sias and Cahill, 1998, p.273; Mao, 2006, p. 1820; Lee and Ok, 2011, p.3) it has been listed the positive effects of workplace friendship at workplace such as it:

- increases support and resources that help individuals to accomplish their job, because friendships at work enchance emotional well-being of the partners of the friendship,

- reduces work stress, feelings of insecurity and uncertainty and provides increased communication, cooperation and energy because workplace firnedships maket hem feel their job important for them,

- increases enthusiasm and a positive attitude at work since workplace friendship flourishes trust among individuals,

- enhances decision-making power and have access to more resources in the

- organization because workplace friendship increases interpersonal relationships and intimacy among coworkers,

- provides employees with support and information exchange, elevating their job performance and thus promotes organizational productivity by improving treatment of depression and anxiety among coworkers through workplace friendship, 
- can buffer job-related stress, and can reduce job dissatisfaction and turnover with the increased sense of loyalty to the organization with an emphathetic sense and culture,

- provides support and third party influence on important decisions because workplace friendship decreases workplace stress,

- makes work more enjoyable and enhances individual creativity at workplaces via workplace friendship that leads to more effective teams that know each other well,

- can increase morale and reduce intention to leave because workplace friendship leads to create larger groups in the organization that can maximize their output,

- leads to higher productivity and improved communication that creates a team atmosphere which enhances the ability to make decisions and manage conflict within the group through workplace friendship that contributes increased feedback good moods among team members in the organization.

\subsection{The Cons of Workplace Friendship}

Despite the positive considerations about workplace friendships, there are risks that are originated from them because workplace friendships may hamper the workflow and teamwork coherence in the organizations. For example, Dickie (2009) argued that when workplace friendships go awry, it can be costly to an organization's productivity since workplace friendships directly involved with work attitudes, work team climate and interpersonal exchange relationships. Additionally, it has been outlined that too much socializing can deteriorate productivity and personal or restricted professional information can be revealed to inappropriate people and cliques can create causing favoritism, exclusivity and negativity in the organizations. Asgharian et al., (2013) mentioned that many organizations abstain from the notion of friendships in the workplace for fear that workplace friendships will lead to the dilemma abiding by the saying that "familiarity breeds contempt" because it's certain that workplace friendships will naturally develop at workplace but they can also have benefits or risks related with them. In more detail, according to Pillemer and Rothbard (2018), when the attitudes or the behaviors required to fulfill instrumental goals conflict with socio-emotional goals, workplace friendships may generate role conflicts and jealousy among individuals or if those excluded from the informal cliques of coworkers feel ostracized and form their own subgroups, creating silos and reducing communication between groups in the organizations. To sum up, as Berman et al. (2002) argued, workplace friendships may result in romantic liaisons and sexual harassment and may undermine employees' loyalty to the organization, strain independent judgement, cause conflict of interest situations among employees, higher levels of perception of organizational politics and may lead to harsh favoritism. Plus, it has been mentioned that workplace friendship leads to political vulnerability in the organization since friends share confidences among them that they might be used against them later unfairly. In conclusion, according to itmeized informaton below (Morrison and Nolan, 2007, pp. 34-37; Kiesel, 2011, pp. 7-8; Berman et al., 2002, pp. 218-219; Pillemer and Rothbard, 2018, pp. 636-638) it has been listed the main disadvantages of workplace friendship:

- individuals usually expect their friends to display special treatment and favoritism, thereby indicating that they regard each other as unique and special and it may lead to restricting constructive criticism especially when one of the friends is the manager,

- friends may find themselves in conflict because of competing interests associated with their work roles or because of a performance evaluation process and it may cause unhealthy competition at workplace, 


\section{Can BİÇER}

- friendships can also have a major "distracting effect" from one's work for excessive chatting, socializing, having "too much fun" and an inability to separate work and it might take away from their work and can't do their jobs on time because of the disruptions and not enough focus on the job,

- friendships may lead to role conflicts when having to issue or take orders from friends and if the boundaries can't be set then it may create jealousy, feelings of a lack of professionalism, and even resentment within the team dynamic in the organization,

- friendships with coworkers may become problematic if the behaviors required to fulfill instrumental goals conflict with socioemotional goals and one of the friends might become the victim of sabotage easily or a backstabbing from someone they trusted.

- when it comes to promotions or project assignments, close friendships can sometimes cause friction and restless in the organization especially when the friends are at the same level and one of them get promoted to a higher position,

- supervisor/subordinate friendship may lead to feelings of unfair treatment by other workers or inaccurate performance assessments, which can, in turn, lead to claims of discrimination, retaliation, and wrongful discharge, so it might be difficult to receive the kind of mentorship and feedback that's needed to grow and thrive and reach organizational goals.

Once again, as Mao and Hsieh (2017) noted in their study, it's obvious that human errors are unavoidable and so common in organizations, they are such problems that can potentially harm performance and work flow at workplaces. So management department in organizations develop systematic approaches to detecting them to prevent from these errors in advance and managers or supervisors often rely on employees to voluntarily speak up disclose the errors they made, however employees often do not disclose their own errors or when they are close friends at work with the intention of not to tattle his/her friends' error. That's because error disclosure is costly from a social and a personal perspective in organizations. Therefore friends at work can be reluctant to disclose each other's errors since error disclosure damages error makers' image on job competence and efficiency in organizations. In the end, organization cannot hear about the error itself and it hampers the efforts and procedures to decrease the personal cost of error disclosure.

As a result, overviewing workplace friendships through their pros and con, just like the saying that "every rose has its thorn", workplace friendships should be evaluated as so natural formations that have positive effects but it must be remembered that they may lead major unwanted situations and consequences that may affect organizations negatively. It can be inferred from the information above, as organizations are simply a network of individuals, when the friendships are better balanced and more professional, the organizations will certainly function better, otherwise productivity and success of the organization on the will be reduced when the friendships don't go on well because of harassment, favoritism, abuse of authority, and conflicts of interest among employees.

\section{HEDGEHOG'S DILEMMA AND WORKPLACE FRIENDSHIPS}

Arthur Schopenhauer wrote about a tale of dilemma about hedgehogs in his series of essays named Parerga und Paralipomena. In a cold day in winter, a group of hedgehogs came closer each other in order to get warm and heated by sharing their body heat but as they come closer their spines on them hurt themselves badly and then they separated and moved away from each other to be more comfortable and feel less pain. In the end, after plenty of uncomfortable huddling each other and freezing going away each other, the hedgehogs found out that the best option was to remain at a little distance from one other. Plus, Sigmund Freud quoted Schopenhauer's parable 
about hedgehogs and he associated hedgehog's dilemma with "sediment of feelings of aversion and hostility" in long-term relationships. And, he raised some rhetorical questions like "How much intimacy can we really endure?" and "How much intimacy do we need to survive in this world?" (De Vries, 2011, pp. 11-12; Huizar, 2019, p.8).

In light of the above, Schopenhauer's "Hedgehog Dilemma" may be the most apposite metaphor for balancing the workplace friendships and viewing about their positive and negative sides in the organizations. Many individuals tend to build relationships with others at work but the truth of individuals' quest of intimate connection is a prickly process at best, because the closer most of them get to true intimacy and vulnerability. According to Sandroni (2019), human relations are hard to build and maintain and these relations that are associated with question of intimacy usually produce stress. It has been mentioned that individuals usually have conflicting sentiments, desiring simultaneously independence and attachment, both fearing and craving those around them but when individuals could resolve their internal conflicts they would know how close they want to be from others, but then a second problem would arise. To sum up, some people may prefer to be emotionally closer and others emotionally more distant. In addition, Bouffard (2014) pointed out that The Hedgehog's Dilemma plays out in daily interactions within teams in organizations and the ability to work in a team and accepting closeness to some extent with others is certainly vital in today's organizations but the reality for most teams is that the employees find it very hard to find the right balance between being close to teammates and keeping a healthy distance each other. That's why individuals often find being on a team causes stress, a burden, or a necessary evil-thus making teamwork even more difficult. However, Kiesel (2011) conducted a study in a publishing company in which 250 individuals were employed in Germany in order to find out the right balance for the workplace friendships. After having gathered the data, individual perceptions and experiences of the 24 employees who were selected for their ages and the years they spent at a publishing company, with the interviewing method from the 24 employees who have worked for the company for the average of 11 years and they were with an average age of 52 years, it was concluded in the study that employees have been very wary to develop friendships at work since majority of them usually not to share their privacy or family life details at work as the friendships might deteriorate in the end. Participants of the study also declared that they tend to keep the number of the friends and the level or prevalence of their friendship limited at work because of the trust, sympathy and relevant factors such as selfdisclosure, office gossip or backstabbing reasons when sharing organizational sources or getting promoted. In addition, Miller (2011) did a research in various organizations consisting of a total of 255 employees participated in this study who were asked to respond to 56 survey questions via questionnaire online. It has been emphasized that it's so common that peer workplace friendships usually develop but when it's time to develop friendships with supervisors, it might be too complex to maintain the friendship at workplace due to creating and managing their own privacy rules through intimacy and professional matters at workplaces. In sum, it has been noted that it can be so problematic when supervisors and subordinates get too close for finding the right balance in the organization about what kind of or to what extent the information is expected to stay private and what kind of information is supposed to be shared with coworkers.

Workplace friendships should also be studied within the concept of social exchange theory (SET) since the friendships depend largely on common interests and sharing via social networks. Since SET refers to social actors engage in interdependent exchanges where the costs and benefits of such exchanges are considered, produce obligation, and can finally cause the development of high-quality relationships, SET can help to discover and interpret workplace behavior of the 


\section{Can BİÇER}

employees and well balanced workplace friendship (Omilion-Hodges et al., 2016, p.348).One of the moderating roles of workplace friendships, social support can enhance the social exchange relationship among friends and especially when employees have a high degree of workplace friendships, they will have social support for obtaining information, advice, and feedback concerning the ethical aspect of handling work duty (Liu et al, 2013, pp. 568-570). From the social exchange theory workplace friendships should be reviewed since it is mainly about "if you do a favor for someone, some reciprocal favor of equal value would be returned. It's also considered that social rewards and social benefits as being uniquely dependent upon personal relationships. For instance, some exchanges occur without any real option of negotiating the costs and rewards. Such exchanges occur because they are defined by the roles and social structures in which the individuals find themselves through how many of their interactions and activities with other people are not social exchanges in the sense of assessing costs and rewards (Redmund, 2015, pp.2-5). Therefore, Yen et al. (2009) stated that workplace friendship helps reduce and even eliminate anxiety in a highly political environment and encourages information sharing and spread among colleagues having better relations and psychological well-being among coworkers as long as keeping the right distance among friends through social exchange theory.

Moreover, Hommelhoff (2019) argued that, although workplace friendships are often considered positively by managers and are usually associated with higher job satisfaction and lower turnover intentions, workplace friendships at work can be undermined by functional, calculative aspects or thinking of career advancement and can lead to emotional exhaustion. Yet, from the point of the proverb "don't mix business with pleasure", it has been discussed as friendships are an essential part of employees' work life and there are also supervisors who think that friendships are neither possible nor desirable at work. In conclusion, in a typical day at work, there are numerous unconscious dynamics that influence human behavior and relationships at work. Workplace friendships are the ones that the German philosopher Arthur Schopenhauer drew an analogy between humans' and hedgehogs' discomfort with social proximity and shed light on the optimum distance for warmth and comfort. That's why most of the employees usually find it confusing and hard to work successfully in groups and teams. And as the hedgehog's dilemma reveals: need for closeness and distance, individuals seek the warmth and closeness of others; on the other hand, they usually can't get around the sharp and spiky bits of themselves, and move away.

To sum up, since the study examines the pros and cons workplace friendships within organizations, the optimum level of workplace friendships should be defined well. For example, Taselli and Kilduff (2018) argued in their study that the necessary elements of openness and favoritism would certainly the cause of the dilemma for both the friends and the norms of discretion and neutrality of the organization sooner or later. They maintained for the optimum level for maintaining the well-balanced workplace friendship is the trust. Because the dilemma will certainly appear when one of the friends to give away the secrets of one of other friends' to another is to betray one's membership of the group. So trust is critical to the brokerage role in workplace friendships and it has been proposed that "self-monitoring" which has been described as "a psychological analogue to bridging structural holes" would be the key for balancing the right level for workplace friendships. Because high self-monitoring individuals will perceive relationships within social networks they tend to assist to coworkers in need and they are skilled at maintaining positive impressions across different groups high self-monitors and they tend to maintain their social standing, including their colleagues' trust, despite their roles in organizations. 


\section{CONCLUSION AND RECOMMENDATIONS}

With the information given above in mind, the aim of this article is to lay out the advantages and the disadvantages of workplace friendships in organizations and the paradoxical situations that the workplace friendships may cause at workplaces. As Song (2006) noted, friendship is one of the essential human values and can affect individual behaviors and attitudes, thus it has various influences on employees' interactions at work. Besides if it's not well balanced or when the things go wrong with workplace friendship, it may lead to unforeseen and negative effects on organizational productivity and organizational unity. So to speak, when employees have higher degrees of workplace friendships, the higher levels of social support for obtaining information, advice, and feedback they will have each other for reaching the organizational goals effectively. On the other hand, if the friendship deteriorates among employees for some reasons, this situation may lead to stress and tension among employees and the work environment might be affected negatively at all levels. So, in order to avoid the disadvantages of friendships at workplace, here are some tips for the individuals and organizations on the whole.

First, being professional and respectful is the key for the healthy workplace friendship at work. As it's obvious that friends at work usually share some personal information, but each friend should be very careful about giving highly personal or family information each other in case work friendship might spiral downward and then, ex-friends can use personal or private information against themselves. Spreading rumors and employees gossip about other people's lives are the most dangerous things for the friendships at work. As a result, it would be too frustrating for the victim and it will directly lead to unrest initially in person then within the organization itself.

Second, confidentiality should be the fundamental ground for the well-balanced friendship at work. Employees must be careful about sharing anything with work friends because it's important whether the management would be happy or not after learning it in the end. It might be dangerous even friends might assure each other about maintaining each other's confidence all the time. Because it can be hard to resist if a higher-up asks them about whatever it is and friends may not be able to keep that promise, and then, employees might lose their jobs if the information shared or gossip leads to tension at work.

Third, being mindful of the office hierarchy in the organization is essential for balancing the friendship. Since, workplace friendships usually involve relationships between employees of unequal age, status, or gender, and friendships might flourish between supervisors and subordinates, between younger and older workers, including mentor/protégé relations, the friendships might be perceived from the point of favoritism or utilitarianism by the coworkers who are not friends of them in the organization. Crossing the hierarchies loutishly and being very sociable and making jokes every time in the office among close friends by overlooking office hierarchy will cause to disturbance in the office and they would responsible for ruining an atmosphere of professionalism at workplace.

Fourth, feeling responsibility about resolving disagreements among friends is another important factor for maintaining the friendships efficiently at work. As friendships aren't always smooth sailing, mild quarrels, conflicts and disagreements can happen any time in teamwork. Therefore, first identifying the source of the disagreements and resolve it in a civil manner and then handling the problems calmly and professionally as much as possible will certainty help the friendships to maintain or leaving the conflicts to be chilled off will help to salvage the friendships at workplace. 


\section{Can BİÇER}

Fifth one is professional boundary is a must and managing the boundaries well is another vital essence for having better friendships at work. Time is the most valuable resource and if friends spend all day shooting the breeze face to face or chatting on social media on their smartphones during office hours, extending lunch time or breaks or unnecessary social interaction with friends at meetings turns into a distraction, finally derailing their abilities to do their daily routine duties and to accomplish organizational goals. Then the supervisors will certainly think that these kinds of reckless friendships destruct the workflow and the performance of the employees as well and take strict precautions in case to resist serious problems in the organization.

Last but not least, authentic friendship is the key for having long-term career success, health and happiness through the sense of belonging, purpose, confidence and satisfaction that everyone would crave and maintaining friendships with coworkers at work is not only socially healthy but also a valuable asset for the organizations. Besides, friendships might be tricky especially when they create arguments or conflicts or in organizations with a more rigid culture or strict hierarchical structure. Therefore, managing workplace friendships in a professional setting properly by establishing reasonable boundaries such as respecting each other's' boundaries at work will help mitigating the probability of frustrating situations and distractions among friends. However, as Sias et al. (2012) argued, workplace friendships can be regarded as unstable or as a "pickle" phenomenon because they are fragile and can be deteriorated because of conflicting personalities, incidents of betrayal, daily routines that become so frustrating for one employee that the other must carry a heavier workload, and the promotion of one partner to a position of formal authority over the other friend. In sum, just like the hedgehogs trying to keep warm on a cold day in winter, but their quills pricked one another and then were obliged to disperse, the closer two employees come to one another in a friendship, the more likely it might be for them to inflict psychological pain on each other, so maintaining the balance between a friendship and a professional working relationship won't be easy but it's essential for avoiding stressful friendships, pain of loneliness and emotional burnout. Last but not least, managers are also responsible for maintaining reasonable social interactions at work because they should set clear expectations of behaviors of the employees in the workplace in advance and the individuals should be informed well because work related issues can easily appear when personal conflicts develop in a friendship.

\section{REFERENCES}

Asgharian, R., Yusoff, R., YaserMazhari, M., Mardani, A., \& HazratSoltan, E. K. (2013). Examining the effect of workplace friendships and job embeddedness on turnover intention (The case of Mashhad as a tourist destination in Iran). International Journal of Business and Management Invention, 2(7), 17-25.

Bader, H. A., Hashim, I. H., \& Zaharim, N. M. (2013). Workplace friendships among bank employees in eastern Libya. Digest of Middle East Studies, 22(1), 94-116.

Bartels, J., Van Vuuren, M., \& Ouwerkerk, J. W. (2019). My colleagues are my friends: The role of Facebook contacts in employee identification. Management Communication Quarterly, 33(3), 307-328.

Berman, E. M., West, J. P., \& Richter, Jr, M. N. (2002). Workplace relations: Friendship patterns and consequences (according to managers). Public Administration Review, 62(2), 217-230. 
Bouffard, W. (2014). The Hedgehog's Dilemma. Puttin' Cologne on the Rickshaw, Internet blog. Retrieved from http://puttincologneontherickshaw.com/authors-blog/the-hedgehogsdilemma/.

Bunnell, T. (2017). Friendship, Geographies of International Encyclopedia of Geography: People, the Earth, Environment and Technology: People, the Earth, Environment and Technology, 1-6. Wiley Online Library. Retrieved from https:// onlinelibrary. wiley.com/ doi/abs/10.1002/9781118786352.wbieg0165

Chen, C. Y., Mao, H. Y., \& Hsieh, A. T. (2012). Role ambiguity, employee gender, and workplace friendship. Psychological reports, 110(3), 719-730.

Chung, S., Lount Jr, R. B., Park, H. M., \& Park, E. S. (2017). Friends with performance benefits: A meta-analysis on the relationship between friendship and group performance. Personality and Social Psychology Bulletin, 44(1), 63-79.

Colbert, A. E., Bono, J. E., \& Purvanova, R. K. (2016). Flourishing via workplace relationships: Moving beyond instrumental support. Academy of Management Journal, 59(4), 1199-1223.

De Vries, M. F. K. (2011). The hedgehog effect: The secrets of building high performance teams. John Wiley \& Sons, San Francisco, CA, U.S.A.

Dickie, C. (2009). Exploring Workplace Friendships in Business: Cultural Variations of Employee Behaviour. Research \& Practice in Human Resource Management, 17(1).

Gordon, J., \& Hartman, R. L. (2009). Affinity-seeking strategies and open communication in peer workplace relationships. Atlantic Journal of Communication, 17(3), 115-125.

Greco, S., Holmes, M., \& McKenzie, J. (2015). Friendship and happiness from a sociological perspective. In Friendship and happiness (pp. 19-35). Springer, Dordrecht.

Hommelhoff, S. (2019). Having workplace friends is not always fun. Zeitschrift für Arbeits- und Organisationspsychologie A\&O.

Huizar, O. A. M. (2019). Hedgehogs. The University of Texas at El Paso, ProQuest Dissertations Publishing, 13883852. Published by ProQuest LLC.

Khaleel, M., Chelliah, S., Khalid, J., Jamil, M., \& Manzoor, F. (2016). Employee engagement as an outcome of friendship at workplace: Moderating role of job embeddedness. International Journal of Academic Research in Business and Social Sciences, 6(6), 1-6.

Kiesel, A. K. G. (2011). Finding the right balance between social relations and profession: Do friendships at work really work out? Unpublished Master's thesis, University of Twente.

Lin, C. T., \& Lu, C. L. (2013, July). The influence of workplace friendship on work values: Taiwan and China. In 2013 Proceedings of PICMET'13: Technology Management in the IT-Driven Services (PICMET) (pp. 1096-1100). IEEE.

Mao, H. Y., \& Hsieh, A. T. (2017). Friendship at work and error disclosure. BRQ Business Research Quarterly, 20(4), 213-225.

Mao, H. Y., Hsieh, A. T., \& Chen, C. Y. (2012). The relationship between workplace friendship and perceived job significance. Journal of Management \& Organization, 18(2), 247-262.

Mao, H. Y. (2006). The relationship between organizational level and workplace friendship. The international journal of human Resource Management, 17(10), 1819-1833. 
Methot, J. R., Melwani, S., \& Rothman, N. B. (2017). The space between us: A social-functional emotions view of ambivalent and indifferent workplace relationships. Journal of Management, 43(6), 1789-1819.

Methot, J. R., Lepine, J. A., Podsakoff, N. P., \& Christian, J. S. (2015). Are workplace friendships a mixed blessing? Exploring tradeoffs of multiplex relationships and their associations with job performance. Personnel Psychology, 69(2), 311-355.

Miller, A. N. (2011). Sharing in workplace friendship: A model of disclosure in white-collar workplace relationships. North Dakota State University.

Morrison, R. L., \& Nolan, T. (2007). Too much of a good Thing? Difficulties with workplace friendships. University of Auckland Business Review, 9(2), 32.

Lee, J. J., \& Ok Ph D, C. (2011). Effects of workplace friendship on employee job satisfaction, organizational citizenship behavior, turnover intention, absenteeism, and task performance. Retrieved from https://scholarworks.umass.edu/cgi/viewcontent. cgi?article $=1053 \&$ context= gradconf_hospitality .

Liu, J., Kwan, H. K., Fu, P. P., \& Mao, Y. (2013). Ethical leadership and job performance in C hina: The roles of workplace friendships and traditionality. Journal of Occupational and Organizational Psychology, 86(4), 564-584.

Li, C. K., \& Hung, C. H. (2009). The influence of transformational leadership on workplace relationships and job performance. Social Behavior and Personality: an international journal, 37(8), 1129-1142.

Omilion-Hodges, L. M., Ptacek, J. K., \& Zerilli, D. H. (2016). A comprehensive review and communication research agenda of the contextualized workgroup: The evolution and future of leader-member exchange, coworker exchange, and team-member exchange. Annals of the International Communication Association, 40(1), 343-377.

Pillemer, J., \& Rothbard, N. P. (2018). Friends without benefits: Understanding the dark sides of workplace friendship. Academy of Management Review, 43(4), 635-660.

Redmond, Mark V., (2015). Social exchange theory. English Technical Reports and White Papers. 5.http://lib.dr.iastate.edu/engl_reports / 5

Riordan, C. M., \& Griffeth, R. W. (1995). The opportunity for friendship in the workplace: An underexplored construct. Journal of Business and Psychology, 10(2), 141-154.

Sandroni, A. (2019). The hedgehog's dilemma. Journal of Mathematical Economics, 82, 184-196.

Sharma, R. (2016). Enhancing Organisational commitment through workplace relationships. International Journal of Management (IJM), 7(3).

Sias, P. M., Gallagher, E. B., Kopaneva, I., \& Pedersen, H. (2012). Maintaining workplace friendships: Perceived politeness and predictors of maintenance tactic choice. Communication Research, 39(2), 239-268.

Sias, P. M. (2005). Workplace relationship quality and employee information experiences. Communication Studies, 56(4), 375-395.

Sias, P. M., \& Cahill, D. J. (1998). From coworkers to friends: The development of peer friendships in the workplace. Western Journal of Communication (includes Communication Reports), 62(3), 273-299. 
The Hedgehog's Dilemma In Organızatıons: The Pros and Cons of Workplace Friendshıp

Song, S. H. (2006). Workplace friendship and employees' productivity: LMX theory and the case of the Seoul city government. International Review of Public Administration, 11(1), 47-58.

Tasselli, S., \& Kilduff, M. (2018). When brokerage between friendship cliques endangers trust: a personality-network fit perspective. Academy of Management Journal, 61(3), 802-825.

Yen, W. W., Chen, S. C., \& Yen, S. I. (2009). The impact of perceptions of organizational politics on workplace friendship. African Journal of Business Management, 3(10), 548. 


\section{GENIŞLETİLMIŞ ÖZET}

\section{Giriş}

Örgütler birden fazla bireyden oluşmaktadır ve bireyler örgütlerin en önemli unsurlarından biridir. Bununla birlikte, bireyler sadece işlerine yoğunlaşmaktan öte birbirleriyle karmaşık, duygusal yoğunluklu ilişkiler de geliştirmektedirler. İşyerleri, arkadaşlık ilişkilerinin geliştirildiği en önemli yerlerden biridir. Bunun nedeni, bireylerin zamanlarının hatta hayatlarının büyük bir kısmını işyerlerinde geçirmeleridir ve bireyler arasında iş hayatıyla birlikte sosyal hayatlarının da harmanlanması fazlasıyla olağandır. Bunun altında yatan en büyük etmen, bireylerin işyerlerinde birbirleriyle sık sık iletişim içinde olmaları ve buna ek olarak yaş, sahip olunan ortak davranış, tutum, siyasi görüş ve öğrenim gibi önemli birçok unsur vardır. İşyerlerinde genellikle aile bireylerinden daha sık bir arada olan çalışanlar, aralarında zamanla gelişen güven duygusu, ortak değerler ve ilgi alanları sayesinde arkadaşlıklar geliştirmektedirler. İşyeri arkadaşlıklarının en büyük özelliği, gönüllülük esasına bağlı olan ve dayatılamayan bir ilişki türüdür ve bireyler işyeri arkadaşlıklarının ortak değerler ve istekleri uyarınca geliştirir, sürdürürler veya sona erdirirler. Yazında, işyeri arkadaşlıklarının hem bireysel hem de örgütsel birçok yararının olduğu vurgulanmış olsa da, olumsuz yönlerinin ve örgütsel hedeflere ulaşmada olumsuz etkilerinin olduğu da vurgulanmaktadır. Bu nedenle, bu çalışma, işyeri arkadaşlıklarının olumlu ve olumsuz yönlerini, ilk kez Arthur Schopenhauer'in 1851'de yayınlanan Parerga ve Paralipomena: Kisa Felsefi Denemeler eserinde bahsedilen "Kirpi İkilemi" bağlamında ele alarak, işyeri arkadaşlıklarının sadece olumlu yönlerini mercek altına almayıp, aynı zamanda olumsuz yönlerini irdeleyerek, işyeri arkadaşlıklarında mesafenin doğru ayarlanabilmesinin önemine vurgu yapmaktadır. Ayrıca bu çalışmada, işyeri arkadaşlıklarının sağduyulu, akıllı, daha kontrollü bir şekilde sürdürülebilmesinin ve örgütsel amaçlarına uygun bir şekilde davranabilme yolları irdelenmekte ve bunlarla ilgili çözüm önerilerinde bulunulmaktadır.

\section{Örgütlerde Kirpi İkilemi: İşyeri Arkadaşlıklarının Olumlu ve Olumsuz Yönleri}

Örgütlerde bireyler, işyeri arkadaşlıkları sayesinde daha etkin ve verimli bir şekilde çalışabilmekte ve daha etkin bilgi paylaşımı yaparak çalışma saatleri dışında da işleriyle ilgili sorunların giderilmesinde daha fazla iletişime geçebilmektedir. Örgütlerde işleriyle ilgili sorunların çözümünde daha fazla yardımlaşma yapabilmelerinin yanı sıra sosyal hayatta yaşamış oldukları sorunların giderilmesi ve hüzünlerinin paylaşılması sayesinde örgüte olumsuz birçok duygunun yansıtılmaması sağlanabilmektedir. İşyeri arkadaşlığına sahip bireyler, işlerine ve içinde bulundukları örgüte olan bağlllılıkları daha fazla olacaktır ve işyeri arkadaşlıkları sayesinde karşılaştıkları sorunları birlikte çözmenin mutluluğunu yaşayarak iş tatminliği daha da artacaktır. Öte yandan, işyeri arkadaşlkklarının da olumsuz yönleri örgütlerde tespit edilebilmektedir. Özellikle örgütsel kaynakların paylaşımında, kaynakların kısıtlı olduğunda, işyeri arkadaşlıklarına sahip bireylerin, birbirleri arasında haksız rekabetin oluşabileceği ve terfi veya ücret artışı nedeniyle kıskançlık ve diğer nedenlerle işyeri arkadaşlıklarının bozularak, iletişim sorunlarının oluşmasına ve sonuç olarak da örgütsel hedeflere ulaşılmasında istenmeyen işyeri gerginlerine yol açabileceği bilinmektedir. Ayrıca, işyeri arkadaşlıkları bozulduğunda, aralarında paylaşmış olukları hem mesleki hem de kişisel Bu çalışma, iş hayatında çalışanların issyeri arkadaşlığında samimi ve içten olmalarının yanı sıra mesafeli olmaları gerektiğini vurgulamakta ve bunu "Kirpi İkilemi" bağlamında ele almaktadır. Kirpi ikilemi kısaca "Bir arada da mı duralım yoksa ayrılalım mı?" sorusunu vurgulamaktadır, yani iki birey ayrıyken acı çekiyor ve yapamıorsa ve acı çektiği için bir araya gelip sonra birleştiği için de acı çekiyor ve yapamıorlarsa, ne yapacağını bilemez, karar veremezler ve bir ikileme düşerler. İşyeri arkadaşlıkları da tam olarak bu ikilemde ele alınmaktadır. Arkadaşlıklarda mesafe iyi 
ayarlanamaz ve duygusal yoğunluklu kararlar alınmaya başlanırsa profesyonellikten çok uzaklaşılacak ve örgütsel hedeflere ulaşmada ciddi sorunlar çıkabilecektir. Tıpkı kirpi ikilemine konu olan ve kışın soğukta 1sınmak için bir araya gelip birbirlerine sokulan kirpilerin sırtlarındaki dikenlerin birbirlerine batması gibi çok yakın ve mesafe konulamayan işyeri arkadaşlıkları bireylere ve örgüte zarar verebilir. Öte yandan, soğukta 1sınmak için birbirlerine sokulan kirpileri canları yandığı için uzaklaşmaları halinde bu sefer de soğuktan donma ihtimalleri de ortaya çıkmaktadır. Bu da, işyeri arkadaşlıkları oluşturamayan, kendini dışlanmış hisseden ve örgütsel bağlılığı belli bir düzeyde kalabilen çalışanları anlatmakta ve işyerinde arkadaşı olmayan bireylerin iletişim ve yardım ağından uzakta kalarak başarısız olabileceğine işaret etmektedir.

\section{Sonuç ve Öneriler}

Yazında işyeri arkadaşlıklarının olumlu yönleriyle ilgili çok fazla araştırma olmasına rağmen olumsuz yönleriyle ilgili çok fazla araştırma bulunmamaktadır. $\mathrm{Bu}$ çalışma, işyeri arkadaşlıklarının önemini ve olumlu yönlerini vurgulamakla kalmayıp olumsuz yönlerinin de olabileciğinin altını çizmektedir. Örgütlerde bireylerin birbirleri arasında geliştirdikleri arkadaşlık ilişkilerinin olumlu ve olumsuz yönleri Arthur Schopenhauer'in ortaya attığ1 "Kirpi İkilemi" kapsamında ele alınmış ve örgütsel hedeflere ulaşılmasında işyeri arkadaşlıklarının olumsuz etkilerinin olabileceği ve bunların olumsuz etkilerinin nasıl azaltılabileceğinin yolları sonuç bölümünde ele alınmıştır. 